Розглядаються оригінальні одночарові $i$ багатошарові структури звукоізоляційних огороджень, а також їх переваги в порівнянні з традиційними аналогами.

Аналізуються недоліки методу оптимізаційного розрахунку групи звукоізоляційних огороджень, призначених для зниження иуму в декількох виробничих приміщеннях. Даний метод має обмежені функціональні можливості, що викликано відносно малим числом иільових функцій $і$ відповідних умов їх використання. 3 огляду на це, запропоновано удосконалений метод оптимізаційного розрахунку групи звукоізолячійних огороджень.

Удосконалення методу полягає в збільшенні числа иільових функцій, призначених для багатоцільової оптимізацї̈ з урахуванням реальних виробничих умов. Доопрацювання алгоритму полягає в попередньому виділенні підгрупи огорож з додатковими вимогами щодо умов експлуатацї (підвищена мічність, пожежна безпека та ін.). При наявності цих умов оператор директивно розподіляє структури $і$ заготовлені матеріали по виділеним огорожам.

Наводиться постановка оптимізаційного завдання групового розрахунку 3 доповненим переліком цільових функцій та обмежень. Даються рекомендацї щодо вибору иільової функиї в конкретних виробничих умовах.

Наводяться нормативні вимоги щодо зниження шуму всередині виробничого приміщення та спектральні характеристики звукоізоляції огорож з різних матеріалів. Також наводяться спектральні характеристики чинного иуму всередині примімення до і після застосування звукоізоляційної огорожі.

Ефективність методу підтверджена стійким зниженням математичного очікування $і$ дисперсіі сумарного навантаження иуму на людей у виробничих приміщеннях зі збільшенням кількості ітерацій. Розрахунковим иляхом продемонстровано зниження надлишкового навантаження иуму в порівнянні зі стандартними методами.

Тим самим підтверджена ефективність удосконаленого методу при розробці групи звукоізолячійних огороджень як технічних засобів охорони праці

Ключові слова: оптимізачія розрахунку звукоізолячійних огорож, надлишкове иумове навантаження, випадковий пошук, безпека

\section{IMPROVEMENT OF THE METHOD OF CALCULATING A GROUP OF SOUND- INSULATING PANELS}

A. Bielikov

Doctor of Technical Sciences, Professor, Head of Department Department of Life Safety*

O. Mamontov

$\mathrm{PhD}$, Associate Professor**

E-mail: aleksandr.mamontov@nure.ua

R. P a p i r n y k

$\mathrm{PhD}$, Associate Professor

Department of Building Technology*

T. S t y t s e n k o

$\mathrm{PhD}$, Associate Professor, Head of Department**

K. Ostapov

$\mathrm{PhD}$

Department of Fire Tactics and Rescue Operations***

V. S h a l o mov

$\mathrm{PhD}$, Associate Professor Department of Life Safety*

S. Ragi mov

$\mathrm{PhD}$, Associate Professor Department of Organization and Technical Support Rescue Operations***

A. Melnichenko Lecturer

Department of Organization and Technical Support Rescue Operations

National University of Civil Defence of Ukraine

Chernyshevska str., 94, Kharkiv, Ukraine, 61023

*Prydniprovska State Academy of Civil Engineering and Architecture Chernyshevskoho ave., 24a, Dnipro, Ukraine, 49600

**Department of Occupational Safety

Kharkiv National University of Radio Electronics Nauky ave., 14, Kharkiv, Ukraine, 61166

***National University of Civil Defence of Ukraine

Chernyshevska str., 94, Kharkiv, Ukraine, 61023

Copyright (C) 2019, A. Bielikov, O. Mamontov, R. Papirnyk,

T. Stytsenko, K. Ostapov, V. Shalomov, S. Ragimov, A. Melnichenko This is an open access article under the CC BY license (http://creativecommons.org/licenses/by/4.0)

\section{Introduction}

Increased noise levels at work harm people's health and reduce productivity. Over the past year, this problem has not lost its relevance in the world [1]. The direct, prolonged effect of noise on people decreases auditory sensitivity at high frequencies and overstrains the central nervous system. This leads to functional changes in many organs and systems, especially the cardiovascular system and the gastrointestinal tract.

In addition to the direct impact on humans, increased noise levels often become an indirect cause of danger due to the effect of sound masking. Individual sounds, including hazard signals and voice messages, become indistinguishable 
against noise. This dramatically increases the risk of accidents and reduces productivity.

Standard methods for calculating sound-insulating panels do not take into account the possibility of simultaneous calculation of a group of panels performed by a single contractor. This is an optimization problem and implies the most advantageous solution under limited materials and financial resources. The formulation of the optimization problem involves various options, each being the most effective in specific production conditions. To improve the method requires an increase in the number of options of the optimization problem and confirmation of their effectiveness. The relevance of the work is dictated by the need to develop the most effective protection of people from noise, taking into account specific production conditions.

\section{Literature review and problem statement}

To date, a number of single-layer and multilayer sound-insulating panels, as well as appropriate calculation methods, have been developed. With no restrictions on weight, thickness and cost, massive panels are the most effective. Otherwise, multilayer structures (sandwich panels) are used. The work [2] is devoted to studies of sound transmission loss characteristics of lattice core sandwich panels. The work noted an improvement in sound loss characteristics compared to a traditional sandwich panel. However, the problem of optimizing the design of sandwich panels is not solved in the work, maximum noise reduction is not achieved with limited materials and economic costs. In [3], an improvement in the sound insulation characteristics of composite sandwich panels with a polyurethane core and laminated composite shells compared to gypsum boards is noted. However, the paper also does not consider the possibility of achieving maximum noise reduction by sound insulation.

In [4], a compromise between the structural and acoustic characteristics of a car body panel is considered. The peculiarities of sound insulation of cars complicate its use in building structures. In [5], multi-purpose optimization of a multi-layer corrugated core sandwich panel is performed. Minimum weight and deflection of the panel are achieved. However, this does not minimize noise and cost. In [6], the weight of sandwich panels is minimized while maintaining a balance of acoustic and mechanical properties. But the problem of noise minimization is not solved. In [7], the dependence of sound insulation of a sandwich panel on stiffness is considered. However, the problem of noise minimization while observing noise regulations is not solved there either.

A hybrid honeycomb core sandwich structure is considered in [8]. Acoustic, mechanical and electromagnetic properties are analyzed. Optimization of the honeycomb core shape increases the sound insulation properties in a certain part of the spectrum. But this leads to a deterioration in mechanical properties, which complicates the widespread use in practice.

In [9], the optimal sound-absorbing coating of a room is calculated. A random selection of materials and area is carried out. Minimum coating cost while observing noise regulations is achieved. However, this work also does not solve the problem of optimizing a group of sound-insulating panels.

The problem of simultaneous optimization of sound-insulating room panels is solved in [10]. This work proposes a method of optimization calculation of a group of sound-insulating panels. A free selection of structures, calculation methods and materials, as well as their distribution over partitions is carried out. After that, the constraints are checked. Due to the multiple stochastic calculation process, a high probability of solutions close to global optimum is achieved. The method involves several options of the optimization problem. The options for the objective function are: excess noise load on people, total noise reduction index, total cost of panels and number of panels manufactured. The calculation confirmed the achievement of the minimum total cost of partitions, and noise levels are presented as limiting conditions. This confirms the effectiveness of one of the options, which emphasizes the economic aspect of the problem. Labor safety is regarded as a secondary condition. In addition, the work does not take into account additional operating conditions, which are often found in practice. These include restrictions on the weight of panels, requirements for strength, fire safety, etc.

This explains the feasibility of conducting a study aimed at improving the method of optimization calculation of a group of sound-insulating panels. The improvement consists in increasing the number of problem options that take into account specific production conditions. Of particular interest is the confirmation of excess noise load minimization as a solution to the labor safety problem, which has not been solved before.

\section{The aim and objectives of the study}

The aim of the study is to find the most advantageous design solution for a group of panels that meets the customer's and contractor's interests. This will provide an opportunity to increase the safety of panels.

To achieve the aim, the following objectives are set:

- to make additions to the statement of the optimization problem of the group calculation of sound-insulating panels, allowing for multi-purpose optimization taking into account the customer's and contractor's interests;

- to improve the method and algorithm of optimization calculation by making additions aimed at improving the safety of panels;

- to confirm the possibility of solving the labor safety problem in the form of reducing the excess noise load (ENL) on people by calculation.

\section{Additions to the statement of the optimization problem of the group calculation of sound-insulating panels}

In addition to the objective function options given in [10], the following criteria multipurpose optimization are proposed:

- criterion that simultaneously takes into account excess noise load, total room noise reduction index and total cost of sound-insulating panels;

- "noise $\times$ cost" product;

- "total noise reduction index/cost".

Multipurpose optimization is recommended when several goals need to be achieved simultaneously. The objective function (1) is a single quality functional and includes the excess noise load, total room noise reduction index and total cost of sound-insulating panels: 


$$
F_{5}=p_{1} F_{1}-p_{2} F_{2}+p_{3} F_{3}-p_{4} F_{4} \rightarrow \min ,
$$

where $p_{1}, p_{2}, p_{3}, p_{4}$ are the weighting factors, depending on the significance of the corresponding indicator and are determined by the standard method of expert assessments; $F_{1}$ is the excess noise load; $F_{2}$ is the total noise reduction index; $F_{3}$ is the total cost of sound-insulating panels [10]. It should be noted that the composition of the terms in the expression (1), taking into account the experts' assessment, can be reduced.

The objective function (2) is the "noise× cost" product:

$$
F_{6}=F_{1} \cdot F_{3}
$$

Function (3) represents the "total noise reduction index/ cost" ratio

$$
F_{7}=F_{2} / F_{3} .
$$

As additional safety conditions (restrictions) for panels, the following are proposed:

- panel bearing capacity;

- panel weight;

- panel thickness;

- fire safety requirements.

The restriction on the panel bearing capacity is used when the ceiling carries an increased load due to redevelopment and installation of additional loads. The restriction of the panel weight is introduced when the ceiling under the panel has a limited bearing capacity. In both cases, these restrictions are introduced to prevent collapse. The thickness restriction is applied when the panel significantly reduces the room size, width of passages, driveways or escape routes. The fire safety requirement also limits the use of a number of materials and structures by introducing standard fire resistance and fire propagation limits.

These additions expand the functionality of the method, make it more versatile and effective in specific production conditions. As a result, there is a possibility of simultaneous interest of the customer and the contractor in achieving the goals. The goal of the customer is to achieve the required safety level of the production process when using panels. The contractor's purpose is to save materials and money in the manufacture of panels.

\section{Improved method and algorithm of optimization calculation of a group of panels}

This optimization problem is given on discrete sets of panels, structures, calculation methods and materials. The objective functions and restrictions are generally nonlinear. Therefore, the problem can be solved by nonlinear discrete programming methods. The most convenient in terms of algorithmic simplicity is the random search method based on the Monte Carlo method [11].

The algorithm of the improved method is shown in Fig. 1. Similar to [10], it uses a stochastic process of random distribution of structures, methods and materials over panels, followed by the selection of the best option.

The improvement of the method and algorithm is in blocks 1 and 2. In block 1, the operator (developer) defines panels with additional requirements for operating conditions described in the previous section of the paper. These requirements include the restrictions on bearing capacity, weight, thickness and fire safety. If there are panels with the specified requirements, the operator allocates them to a separate subgroup. Further, in block 2, the operator purposefully (directively) distributes structures and materials among them. Thus, part of the problem solution is taken over by the person. In the further search for solutions, the selected subgroup of panels is not involved. At the same time, the decision made affects the value of the objective function and the fulfillment of limiting conditions.

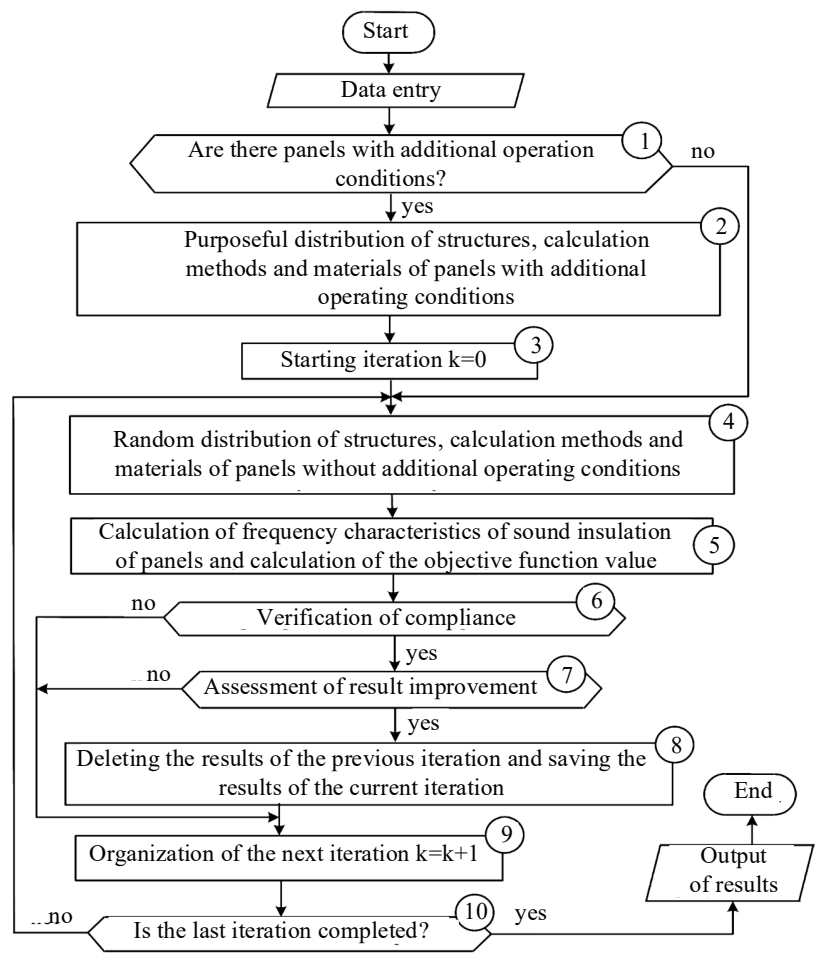

Fig. 1. Scheme of the algorithm for calculating a group of panels

The introduction of blocks 1 and 2 is aimed at improving the safety of panels. This also helps to reduce computation and improve optimization results.

The remaining blocks of the algorithm correspond to the description given in [10].

\section{Confirmation of the possibility of reducing excess noise load on people}

Fig. 2 shows the graphical dependences of random numbers of materials distributed over the panels $j 1-j 4$ on the iteration number k. Material number values correspond to break points. It was allowed to use single-layer panels made of stone and sheet materials with a total number of 16 . Stone materials included concrete and silicate brick. The thickness of the panel made of these materials took the values of 150 and $280 \mathrm{~mm}$ (including plaster). Sheet materials included asbestos cement, gypsum board and wood fiber of $8 ; 12 ; 20$; $22 \mathrm{~mm}$ thickness.

This procedure is implemented using block 4 of the algorithm. A computer program that implements the algorithm was compiled in Mathcad [12]. Number generation was performed using the $\operatorname{rnd}(n)$ function, which generated evenly distributed material numbers in the range from 0 to $n$ (16). 


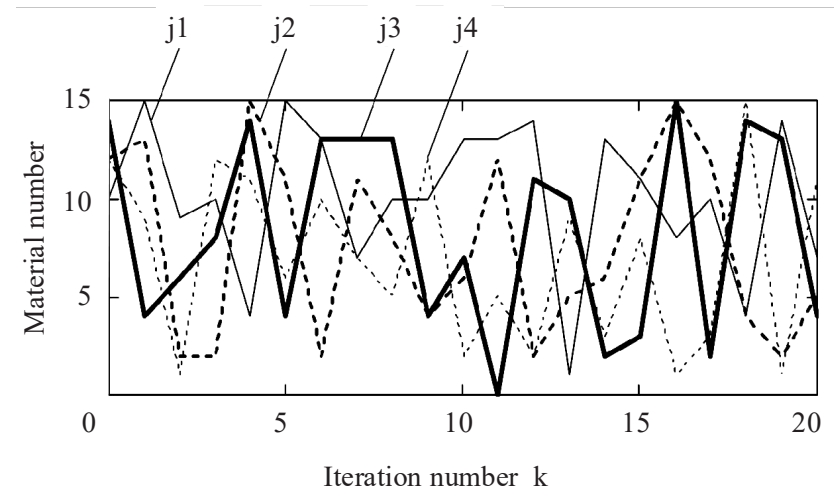

Fig. 2. Graphs of random distribution of materials among panels: j1...j4 - panel numbers

Fig. 3 shows the graphical dependences of excess noise load $(I N R)$ in four rooms corresponding to the iteration number. The excess noise load values correspond to break points. The excess noise load was the objective function and calculated by the formula [10]:

$$
F_{1}=E N L=3,600 \sum_{j=1}^{m} \sum_{i=1}^{n}\left(\Delta I_{j i} \cdot 10^{0.1 A} \cdot t_{j}\right) \rightarrow \min
$$

where $E N L$ is the excess noise load, $\mathrm{W} \cdot \mathrm{h} / \mathrm{m}^{2} ; \Delta I_{j i}$ is the excess noise intensity in a separate room without correction "A", $\mathrm{W} / \mathrm{m}^{2} ; j$ is the number of the panel (room); $m$ is the number of panels; $i$ is the number of the one-third-octave band; $n$ is the number of one-third-octave bands where the sound pressure level exceeds the norm; $A$ is sound correction in accordance with the characteristic "A", $\mathrm{W} / \mathrm{m}^{2} ; t_{j}$ is the duration of room noise action, $\mathrm{h}$

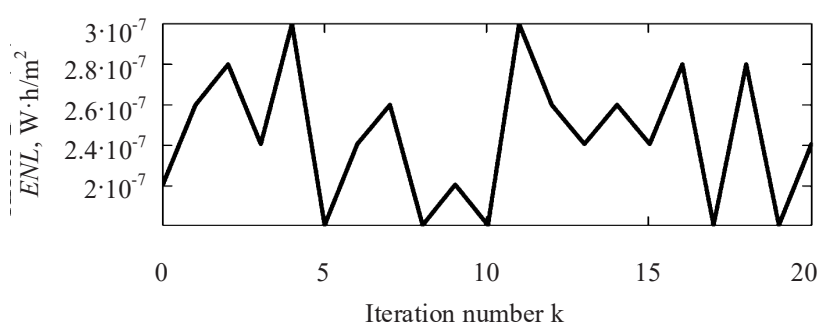

Fig. 3. Values of the objective function ENL depending on the iteration number $\mathrm{k}$

For clarity, the number of iterations in Fig. 3 is 20. Despite the small number of iterations, it is clear that the objective function takes different values. Obviously, to obtain an acceptable solution that satisfies the customer requires more iterations. This confirms the possibility of reducing the excess noise load $(E N L)$ on people.

\section{Practical implementation}

As an example, a group of four production facilities with elevated levels of sound pressure from external sources is considered. Fig. 4 shows the frequency characteristics of the limit spectrum [13] and noise in one of the rooms without taking into account the sound-insulating panel.

As a result of computation, various panel options were obtained meeting the cost and weight restrictions. Fig. 5 shows the possible frequency characteristics of the sound-insulating panel in one of the four rooms. Number 1 - the characteristic of the gypsum board with a thickness of $22 \mathrm{~mm}, 2$ - fiberboard with a thickness of $22 \mathrm{~mm}$. Number 3 indicates the characteristic of a $12 \mathrm{~mm}$ thick fiberboard, number 4 - a $20 \mathrm{~mm}$ thick gypsum board. The gypsum board with a thickness of $12 \mathrm{~mm}$ is represented by the characteristic number 5 , and the fiberboard with a thickness of $12 \mathrm{~mm}$ is represented by the characteristic number 6 .

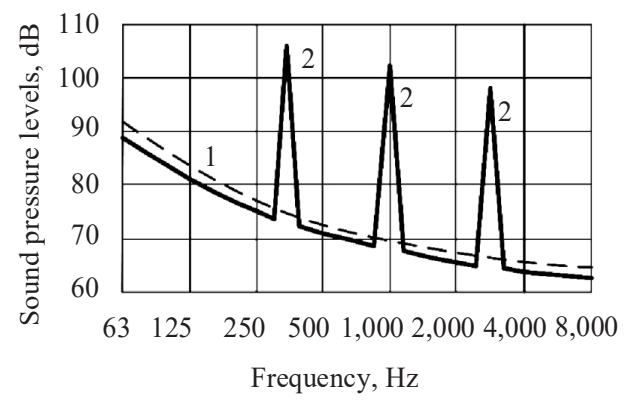

Fig. 4. Noise spectral characteristics: 1 - limit spectrum No. $70 ; 2$ - noise

All frequency characteristics shown in Fig. 5 were obtained according to the standard procedure [13]. Of the six options, only option number 2 (22 $\mathrm{mm}$ thick fiberboard) allows reducing noise in the room to acceptable sound pressure levels (limit spectrum). The upper break point of line 2 has the following coordinates. On the abscissa axis: $19,000 / 22=864 \mathrm{~Hz}$ (taking into account rounding to the nearest geometric mean frequency of the $1 / 3$ octave band $800 \mathrm{~Hz}$ ). On the ordinate axis $-35 \mathrm{~dB}$. The lower break point has an abscissa coordinate: $38,000 / 22=1,727 \mathrm{~Hz}$ $(1,600 \mathrm{~Hz})$. On the ordinate axis $-29 \mathrm{~dB}$. Straight lines to the left and right from the break points with slopes of $4.5 \mathrm{~dB} /$ oct and $7.5 \mathrm{~dB}$ /oct, respectively, are plotted.

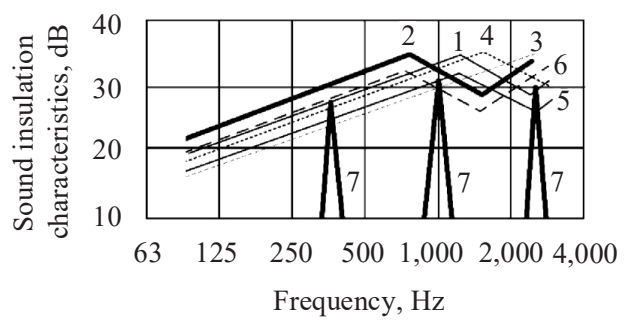

Fig. 5. Frequency characteristics: $1-6-$ noise insulation using single-layer thin panels; 7 - required noise reduction

The frequency characteristics of sound-insulating panels in the remaining three rooms do not differ fundamentally from the characteristics shown in Fig. 5. Therefore, they are not given in this paper. The dimensions of the rooms and the power of the noise sources were not taken into account in the calculation. This is due to the fact that the methods [13] take into account noise propagation only through a sound-insulating panel. Therefore, the noise inside the rooms in question depends only on the properties of sound insulation.

The total cost of panels and the physical properties of materials can be estimated using Table 1 [14]. The unit cost and specific weight of materials are given taking into account fasteners (for fiber and gypsum boards), mortar and plaster (for brick wall). The total cost limit was 
9,100 c.u. The weight limit for a single panel was $730 \mathrm{~kg}$. Taking into account satisfactory spectral characteristics of sound insulation, a $22 \mathrm{~mm}$ thick fiberboard (one panel) and $12 \mathrm{~mm}$ thick gypsum board (three panels) were used. The total cost of the panels was 9,040 c.u. It is easy to verify that the brick wall did not meet the cost and weight restrictions.

Table 1

Unit cost and specific weight of panel materials

\begin{tabular}{|c|c|c|c|c|}
\hline $\begin{array}{c}\text { Material name } \\
\text { and partition } \\
\text { thickness }\end{array}$ & $\begin{array}{c}\text { Unit cost of } \\
\text { materials, } \\
\text { c.u. } / \mathrm{m}^{2}\end{array}$ & $\begin{array}{c}\text { Panel } \\
\text { cost, } \\
\text { c.u. }\end{array}$ & $\begin{array}{c}\text { Specific } \\
\text { panel weight, } \\
\mathrm{kg} / \mathrm{m}^{2}\end{array}$ & $\begin{array}{c}\text { Panel } \\
\text { weight, } \\
\mathrm{kg}\end{array}$ \\
\hline $\begin{array}{c}\text { Fiberboard, } \\
12 \mathrm{~mm}\end{array}$ & 45 & 1,550 & 13.2 & 396 \\
\hline $\begin{array}{c}\text { Fiberboard, } \\
20 \mathrm{~mm}\end{array}$ & 83 & 2,690 & 22 & 660 \\
\hline $\begin{array}{c}\text { Fiberboard, } \\
22 \mathrm{~mm}\end{array}$ & 91 & 2,920 & 24.2 & 726 \\
\hline $\begin{array}{c}\text { Gypsum board, } \\
12 \mathrm{~mm}\end{array}$ & 32 & 2,040 & 14 & 420 \\
\hline $\begin{array}{c}\text { Gypsum board, } \\
20 \mathrm{~mm}\end{array}$ & 52 & 1,760 & 23 & 690 \\
\hline $\begin{array}{c}\text { Gypsum board, } \\
22 \mathrm{~mm}\end{array}$ & 57 & 1,910 & 25.3 & 759 \\
\hline $\begin{array}{c}\text { Silicate plas- } \\
\text { tered brick, } \\
150 \text { mm }\end{array}$ & 390 & 11,700 & 308 & 9,225 \\
\hline
\end{tabular}

Fig. 6 shows the distribution polygons [15] of the excess noise load in the rooms depending on the number of iterations $\mathrm{K}$.

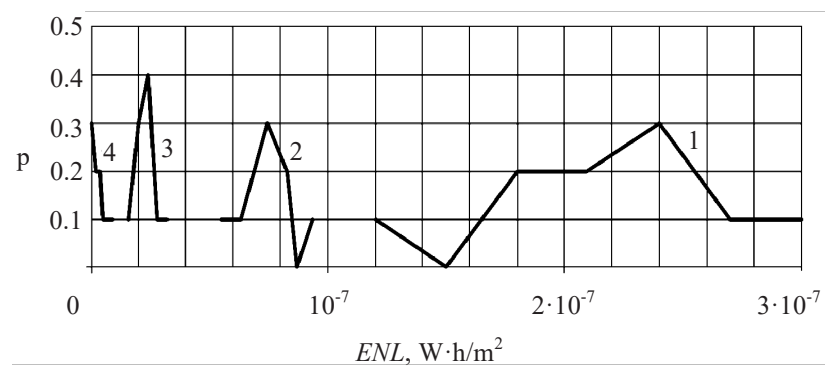

Fig. 6. Distribution polygons of excess noise load depending on the number of iterations (Mathcad):

$1-K=10^{2} ; 2-K=10^{3} ; 3-K=10^{4} ; 4-K=10^{5}$

Fig. 7, 8 present the diagrams of the mathematical expectation and variance [15] of the excess noise load depending on the number of iterations.

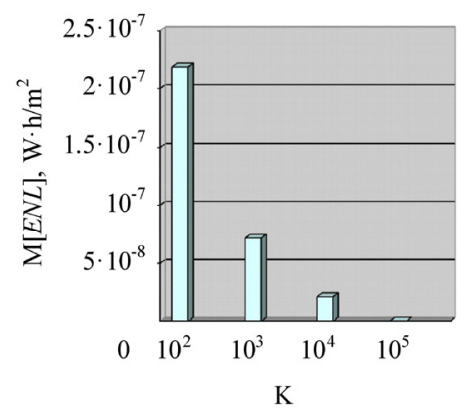

Fig. 7. Mathematical expectation of excess noise load

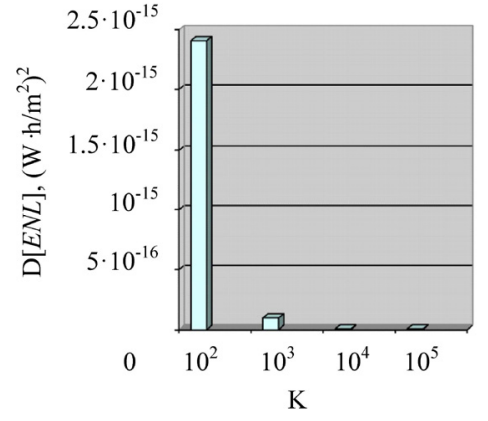

Fig. 8. Variance of excess noise load

Evaluation of the obtained results demonstrated a steady reduction of excess noise load as an objective function with an increase in the number of iterations. Compared to standard engineering calculation methods [10], the improved method allows reducing the excess noise load by approximately an order of magnitude. This can be seen by looking at the results presented in Fig. 6-8. Using traditional methods, the developer does not know the optimal combination of materials and their distribution over panels. The choice of materials is usually random, and the number of calculated options is rather small (units). In rare cases, the number of options is tens. Therefore, the obtained result at best corresponds to calculations with the number of iterations $10^{2}$. As can be seen in Fig. 6 and 7, the mathematical expectation of excess noise load is $2.2 \cdot 10^{-7} \mathrm{~W} \cdot \mathrm{h} / \mathrm{m}^{2}$.

\section{Discussion of the results of studying the possibility of improving the safety of sound-insulating panels}

The results of the study are explained by the solution of the problems. The advantage of this method in comparison with analogs [2-9] is the possibility of optimization of sound-insulating panels.

Additions made to the statement of the optimization problem [10] expanded the functionality of the method, made it more versatile and popular. This became possible due to the introduction of additional objective functions (1)-(3), intended for multipurpose optimization and extending search directions.

The introduction of additional limiting conditions (weight, bearing capacity, thickness and fire safety) allowed reducing the threat of destruction, fire and evacuation obstacles during the operation of panels.

The introduction of additions in the form of blocks 1 and 2 (Fig. 1) makes the method more advanced than the analog [10]. The additions increase the safety of panels, reduce computation and improve optimization results.

As a result of these additions, it became possible to simultaneously achieve the customer's and contractor's goals. The goal of the customer is to achieve the required safety level, including requirements to noise reduction and safety of panels. The goal of the contractor is to save materials and financial resources for the manufacture of panels.

The study confirmed the possibility of solving the labor safety problem to reduce noise impact on people. In contrast to [10], where the economic problem of minimizing the total cost of panels is actually solved, this work minimizes the excess noise load on people.

Minimization of excess noise load is achieved using random search based on the Monte Carlo method. As a result of 
the multiple stochastic calculation process, a large number of panel options are evaluated, from which the best option is selected. An increase in the number of iterations contributes to the persistent improvement of optimization results. This is evidenced by the distribution polygons, diagrams of mathematical expectation and variance of excess noise load in Fig. $6-8$, respectively.

This method is characterized by relative algorithmic simplicity and low rate of convergence. Therefore, its application is limited by the number of sound-insulating panels, structures, calculation methods and materials. The number of elements in these discrete sets can be units and should not exceed 10. Otherwise, the result becomes unattainable due to large amounts of computation. This is a major drawback of this study. To eliminate it, other optimization methods are required. However, even in this case, the statement of the optimization problem presented in this paper can be used.

Further work in this direction should be associated with the selection of the most effective optimization method and development of appropriate software.

\section{Conclusions}

1. The method and algorithm of optimization calculation of a group of sound-insulating panels against airborne noise are improved. The improvement consists in the possibility of preliminary purposeful determination of structures and materials for a specific subgroup of panels. This improvement allows taking into account additional safety requirements for panels. This extends the functionality of the method.

2. As additions to the objective functions, multipurpose optimization criteria are proposed:

- criterion that simultaneously takes into account excess noise load, total room noise reduction index and total cost of sound-insulating panels;

- "noise $\times$ cost" product;

- "total noise reduction index/cost".

Additional restrictions include:

- panel bearing capacity;

- panel weight;

- panel thickness;

- fire safety requirements.

Thanks to this, the developer is able to search for the optimum in new directions. The additions also expanded the functionality of the method.

3. Based on the calculations, the achievement of an acceptable solution is demonstrated. As a result of using the improved method, the total noise load on people is reduced by about an order of magnitude (from $2.2 \cdot 10^{-7}$ to $0.5 \cdot 10^{-8} \mathrm{~W} \cdot \mathrm{h} / \mathrm{m}^{2}$ ). This effect helps to increase productivity and safety.

\section{References}

1. Health statistics and information systems. World Health Organization. Available at: https://www.who.int/healthinfo/statistics/en/

2. Ehsan Moosavimehr, S., Srikantha Phani, A. (2017). Sound transmission loss characteristics of sandwich panels with a truss lattice core. The Journal of the Acoustical Society of America, 141 (4), 2921-2932. doi: https://doi.org/10.1121/1.4979934

3. Patinha, S., Cunha, F., Fangueiro, R., Rana, S., Prego, F. (2014). Acoustical Behavior of Hybrid Composite Sandwich Panels. Key Engineering Materials, 634, 455-464. doi: https://doi.org/10.4028/www.scientific.net/kem.634.455

4. Cameron, C. J., Lind Nordgren, E., Wennhage, P., Göransson, P. (2014). On the balancing of structural and acoustic performance of a sandwich panel based on topology, property, and size optimization. Journal of Sound and Vibration, 333 (13), 2677-2698. doi: https://doi.org/10.1016/j.jsv.2014.01.025

5. Khalkhali, A., Narimanzadeh, N., Khakshournia, S., Amiri, S. (2014). Optimal design of sandwich panels using multi-objective genetic algorithm and finite element method. International Journal of Engineering, 27 (3), 395-402. Available at: http://www.ije.ir/ article_72266_adb3b989a7941894512bf7c6927b94ed.pdf

6. Wang, T., Li, S., Nutt, S. R. (2009). Optimal design of acoustical sandwich panels with a genetic algorithm. Applied Acoustics, 70 (3), 416-425. doi: https://doi.org/10.1016/j.apacoust.2008.06.003

7. Leite, P., Thomas, M., Simon, F., Bréchet, Y. (2014). Optimal Design of a Multifunctional Sandwich Panel With Foam Core: Lightweight Design for Flexural Stiffness and Acoustical Transmission Loss. Advanced Engineering Materials, 17 (3), 311-318. doi: https://doi.org/10.1002/adem.201400075

8. Li, Q., Yang, D. (2018). Mechanical and Acoustic Performance of Sandwich Panels With Hybrid Cellular Cores. Journal of Vibration and Acoustics, 140 (6). doi: https://doi.org/10.1115/1.4040514

9. Belikov, A. S., Sokolov, I. A., Shalomov, V. A., Mamontov, A. V. (2017). Improving safety in workplaces when operating the compressor units for the account of improving the calculation of sound absorption coatings. Heotekhnichna mekhanika, 135, $246-257$.

10. Mamontov, O., Stytsenko, T. (2019). Development of a method for optimization calculation of a group of sound-insulating panels for airborn noise protection. Eastern-European Journal of Enterprise Technologies, 3 (10 (99)), 32-38. doi: https://doi.org/ 10.15587/1729-4061.2019.170079

11. Mistakidis, E. S., Stavroulakis, G. E. (1998). Nonconvex Optimization in Mechanics: Algorithms, Heuristics and Engineering Applications by the F.E.M. Springer, 288. doi: https://doi.org/10.1007/978-1-4615-5829-3

12. Gurskiy, D., Turbina, E. (2006). Vychisleniya v MATHCAD 12. Sankt-Peterburg: Piter, 544.

13. Kiseleva, E. G. (2011). Raschet zvukoizolyatsii ograzhdayushchih konstruktsiy zhilyh i obshchestvennyh zdaniy. Moscow: MARHI, 52.

14. Soundproofing materials and acoustic Solutions. Sound Servise. Available at: http://www.keepitquiet.co.uk/

15. Rybalko, O. M. (2014). Vyshcha matematyka (spetsialni rozdily). Osnovy teoriyi ymovirnostei z elementamy matematychnoi statystyky. Kharkiv: Kolehium, 359. 